\title{
Tekanan Orangtua, Perfeksionisme, dan Ketidakjujuran Akademik pada Pelajar di Jakarta \author{
Students in Jakarta)
} \\ (Parental Pressure, Perfectionism, and Academical Dishonesty among
}

\author{
LUTHFI LUSIANE ${ }^{1}$, GARVIN $^{2}$ \\ Program Studi Psikologi, Universitas Bunda Mulia
}

Email: 1'luthfilusi25@gmail.com, ${ }^{2}$ garvin.goei@gmail.com

\begin{abstract}
Abstrak: Ketidakjujuran akademik merupakan salah satu fenomena yang sudah lama terjadi dalam dunia pendidikan dan masih menarik untuk diteliti. Diketahui bahwa ketidakjujuran akademik ini meningkat secara dramatis setiap tahunnya dalam beberapa dekade terakhir. Penelitian ini menghipotesiskan bahwa tekanan orangtua dan perfeksionisme berhubungan dengan ketidakjujuran akademik. Pengambilan data dilakukan kepada 600 pelajar di Jakarta yang berusia antara $14-18$ tahun. Pengambilan data dilakukan dengan menggunakan kuesioner yang berisi Children-Adolescence Perfectionism Scale (CAPS), Perceived Parental Pressure Inventory (PPPI), dan Academic Dishonesty Scale; ketiganya diterjemahkan oleh peneliti ke dalam Bahasa Indonesia sebelum digunakan dalam penelitian. Hasil uji korelasi menunjukkan bahwa: (1) tekanan orangtua berhubungan secara positif dan signifikan dengan ketidakjujuran akademik, (2) perfeksionisme berhubungan secara positif dan signifikan dengan ketidakjujuran akademik, dan (3) tekanan orangtua berhubungan secara positif dan signifikan dengan perfeksionisme. Penelitian ini menyarankan agar orangtua lebih memerhatikan kondisi anak dan tidak memaksakan standar prestasi akademik yang terlalu tinggi agar anak tidak mengembangkan perfeksionisme dan melakukan ketidakjujuran akademik untuk memenuhi standar tersebut.
\end{abstract}

Kata Kunci: ketidakjujuran akademik, pelajar, perfeksionisme, tekanan orangtua

Abstract: Academic dishonesty is one phenomenon that has long happened in the world of education and is still interesting to study. It is known that academic dishonesty has increased dramatically each year in the past few decades. This study hypothesized that parental pressure and perfectionism are related to academic dishonesty. Data collection was carried out for 600 students in Jakarta between the ages of 14-18 years; using a questionnaire containing the Children-Adolescence Perfectionism Scale (CAPS), Perceived Parental Pressure Inventory (PPPI), and Academic Dishonesty Scale; all of these three were translated by researchers into Bahasa Indonesia before being used in research. Correlation test results showed that: (1) parental pressure is positively and significantly related to academic dishonesty, (2) perfectionism is positively and significantly related to academic dishonesty, and (3) parental pressure is positively and significantly related to perfectionism. This study suggested that parents should pay more attention to the child's condition and do not impose too high academic achievement standards so that children do not develop perfectionism and commit academic dishonesty to meet these standards.

Keywords: academic dishonesty, parental pressure, perfectionism, students

\section{PENDAHULUAN}

Ketidakjujuran akademik merupakan salah satu permasalahan yang sering muncul dalam dunia pendidikan yang frekuensinya semakin meningkat. Dewasa ini, perilaku ketidakjujuran akademik semakin berkembang di kalangan remaja di sekolah-sekolah di seluruh dunia dan terus meningkat secara 
dramatis setiap tahunnya, yang mana masalah ini terjadi mulai dari tingkat pendidikan sekolah dasar (SD) hingga ke perguruan tinggi. Dalam penelitian yang dilakukan oleh Cizek (dalam Anderman \& Murdock, 2006), ditemukan bahwa satu pertiga dari pelajar usia sekolah dasar melakukan kecurangan. Studi yang dilakukan oleh Educational Testing Service pada tahun 2010, menyontek yang dilakukan oleh Siswa Menengah Atas meningkat secara statistik selama 70 tahun terakhir, di mana pada tahun 1940 hanya 20\% mahasiswa yang mengaku pernah menyontek saat SMA, namun sekarang sekitar 75-98\% mahasiswa mengaku pernah menyontek (The Daily Nerbaskan, 2017). Survei terbaru yang dilakukan oleh Kessler International (2017) pada 300 mahasiswa, 9 dari 10 mahasiswa, atau sebesar $86 \%$ mengaku pernah menyontek, dan hanya sebesar $12 \%$ mahasiswa yang mengaku tidak pernah menyontek karena alasan etika.

Kondisi tersebut tidak jauh berbeda dengan kondisi di Indonesia. Survei online yang dilakukan oleh Pusat Psikologi Terapan Jurusan Psikologi Universitas Pendidikan Indonesia (UPI) sejak tahun 2004-2013 pada 597 responden dari 68 kota menemukan bahwa kecurangan saat UN terjadi secara massal yang juga melibatkan peran guru, kepala sekolah, dan pengawas (Suara Pembaruan, 2013). Survei yang dilakukan oleh Litbang Media Group (2007) kepada 480 responden dewasa di enam kota besar di Indonesia yaitu Makasar, Surabaya, Yogyakarta, Bandung, Jakarta, dan Medan menunjukkan bahwa mayoritas anak didik melakukan ketidakjujuran akademik dalam bentuk menyontek (Nursalam, Bani, \& Munirah, 2013; Pradana \& Lestari, 2016). Survei lain yang dilakukan oleh Komisi Pembelajaran ITB terhadap 8.182 mahasiswa ITB tahun ajaran 2009/2010, ditemukan sebanyak 58\% mahasiswa mengaku berbuat curang saat mereka di SD, sebanyak $78 \%$ saat di SMP, $80 \%$ saat di SMA, dan mengalami penurunan menjadi hanya sebesar $37 \%$ saat mereka telah menjadi mahasiswa (Kompas.com dalam Lestari \& Asyanti, 2015).

Meskipun setiap institusi pendidikan memiliki peraturan dalam menyikapi ketidakjujuran akademik yang dilakukan oleh peserta didik, namun pada kenyataannya masih terdapat peserta didik yang melakukan ketidakjujuran akademik tersebut. Penelitian yang dilakukan di Amerika Utara oleh Anderman, Griesinger, dan Westerfield (dalam Bjorkblund \& Wenestam, 1999) mengklaim bahwa obsesi mendapat nilai yang tinggi di sekolah mendorong munculnya tindakan 
curang. Selain itu, beban studi yang berlebih, tingkat stres siswa, sikap pengajar, dan meningkatnya ketidakpatuhan terhadap aturan akademis juga merupakan faktor pendorong perilaku curang (Bjorklund \& Wenestam, 1999). Diketahui bahwa perilaku menyontek disebabkan oleh dua faktor, yaitu faktor internal dan eksternal (Kusrieni, 2014). Faktor internal yang menyebabkan perilaku menyontek adalah kurangnya pengetahuan dan pemahaman tentang menyontek, rendahnya self-efficacy, status sosial ekonomi, nilai moral, kemampuan akademik yang rendah, time management, dan prokrastinasi. Sedangkan faktor eksternal yang memengaruhi perilaku menyontek adalah tekanan dari teman sebaya, orangtua, dan sikap guru yang kurang tegas terhadap perilaku menyontek itu sendiri (Khairat, Maputra, \& Rahmi, 2014).

Taylor et. al. (dalam Sarita, 2015) mengatakan bahwa kecurangan akademik lebih mungkin terjadi karena tekanan orangtua terhadap anak-anaknya untuk mendapatkan nilai yang bagus. Para remaja tak jarang mengambil risiko untuk menyenangkan orangtua mereka atau untuk menjadi yang lebih baik daripada saudara atau teman-temannya, dan akhirnya melakukan kecurangan akademik karena mereka percaya bahwa jika mereka curang kemudian mereka akan memperoleh nilai bagus yang mereka atau orangtua mereka inginkan (Sarita, 2015). Moeck (dalam Sarita, 2015) menambahkan bahwa dengan tekanan yang luar biasa dan kompetisi dalam memperoleh nilai, beberapa siswa akan menyontek atau melakukan plagiat untuk mempertahankan nilai yang tinggi, yang mana salah satu alasannya adalah untuk dapat menyenangkan orangtua.

Orangtua, melalui pilihan dan keputusan yang dibuat untuk diri mereka dan anak-anak mereka, mempengaruhi bagaimana anak-anak tumbuh dan berkembang (Letha, 2013). Anak-anak sebenarnya sudah mulai menyadari apa yang orang dewasa harapkan dari mereka ketika mereka berada di usia sekolah dasar, yang mana ekspektasi terhadap mereka tersebut meningkat ketika mereka memasuki masa remaja (McDevitt \& Ormrod, 2014). Pada masa remaja, para orang dewasa meningkatkan ekspektasi mereka pada sang remaja, yang mana ekspektasi tersebut tidak mudah untuk dipenuhi oleh remaja (McDevitt \& Ormrod, 2014). Orangtua dengan ekspektasi yang tinggi cenderung menetapkan standar yang tinggi terhadap prestasi anak dan lebih mungkin untuk terlibat dalam pendidikan anaknya daripada orangtua dengan ekspektasi 
yang rendah (Ma, Siu, \& Tse, 2018). Tidak jarang orangtua menekan anak mereka sehingga banyak remaja yang akhirnya menjadi stres karena tekanan orangtua terhadap akademik mereka tinggi (Sarita, 2015; Sangma, Akoijam, Maisnam, Visi, \& Vanlalduhsaki, 2018).

Keterlibatan orangtua terhadap pendidikan anak mereka di tingkat menengah atas kurang terlihat (Ferguson \& Rodriguez, 2005) dikarenakan pada masa ini berhubungan dengan meningkatnya otonomi dan individuasi remaja. Namun Shaver \& Walls (dalam Ferguson \& Rodriguez, 2005) menemukan bahwa orangtua memiliki keinginan untuk terlibat dalam perkembangan anak-anak remaja mereka, salah satunya dalam pendidikan mereka. Orangtua menjadi takut karena remaja mulai membuat keputusan mereka sendiri yang mana keputusan tersebut akan memengaruhi kehidupan mereka selanjutnya sehingga mereka menjadi lebih suportif dan protektif daripada yang seharusnya (Kim \& Schneider, 2005 dalam Benner, Boyle, \& Sadler, 2016), yang mana sikap suportif dan protektif orangtua menjadi berbeda dalam konteks pendidikan (Costa \& Faria, 2017).

Tekanan yang berlebihan dari orangtua membuat banyaknya anak-anak menjadi jatuh.
Pope (2001), dalam bukunya, mengungkapkan bahwa tekanan dari orangtua dan sekolah untuk mencapai nilai terbaik membuat level stres di kalangan pelajar, dimulai dari sekolah dasar, yang sangat tinggi. Tekanan orangtua menjadi prediktor negatif bagi pencapaian akademik mereka. Berdasarkan hasil penelitian yang dilakukan oleh Kung (2016), tekanan yang berlebih akan mengarah pada pencapaian akademik yang rendah. Selain itu, tekanan yang berlebih untuk melakukan yang tebaik di sekolah dapat menyebabkan anak-anak melakukan hal yang tidak etis.

Tingginya tekanan serta sulitnya untuk mencapai nilai bagus yang mereka atau orangtua mereka inginkan dapat membuat mereka menjadi stres, dan siswa-siswa yang merasa tertekan dan mereka yang berjuang secara akademik menjadi memiliki keyakinan bahwa dengan melakukan ketidakjujuran merupakan satu-satunya jalan untuk segala kesuksesan. Hal ini dibuktikan oleh hasil survei yang dilakukan oleh Josephson Institute of Ethics (2009) terhadap 6.930 resonden dalam lima kelompok usia, yaitu usia 17 tahun kebawah, 18-24 tahun, 25-40 tahun, 41-50 tahun, dan 51 tahun keatas, menemukan bahwa remaja berusia 17 tahun kebawah (51\%) lima kali lebih mungkin untuk mempercayai bahwa 
berbohong dan berlaku curang merupakan hal yang perlu mereka lakukan untuk berhasil. Persepsi para siswa terkait tindak ketidakjujuran tersebut dapat berkontribusi terhadap perilaku mereka di tempat kerja (Saana, Ablordeppey, Mensah, \& Karikari, 2016). Hasil penelitian juga menunjukkan bahwa mereka yang curang saat masih menuntut ilmu akan lebih mungkin untuk berbuat curang saat bekerja (Eastman, Iyer, \& Reisenwitz, 2008; Nursalam, Bani, \& Munirah, 2013). Selain itu, individu yang memilih untuk tidak jujur saat di SMA dan perguruan tinggi dapat sangat sulit untuk menghilangkan perilakunya pada saat ia berada di tempat kerja (Rujoiu \& Rujoiu, 2014). Gillespie (dalam Rujiou \& Rujiou, 2014) juga mengatakan bahwa ketidakjujuran akademik yang mengarah pada ketidakjujuran di tempat kerja memiliki kemampuan untuk menyakiti karyawan lain ketika pekerjaan tersebut membutuhkan karyawan yang jujur dan produktif. Oleh karena itu, sangat penting untuk menekan segala bentuk kecurangan akademik.

Selain terkait dengan masalah etika di masa depan, dalam hal ini orangtua merupakan individu yang paling dekat dengan anak dan memiliki tanggung jawab terhadap anak mereka, membentuk sikap dan perilaku anak agar dapat mencapai pola perilaku yang diharapkan (Palar, Palandeng, \& Kallo, 2015), dan kualitas dari interaksi antara orangtua dan anak merupakan mekanisme perkembangan yang berpengaruh pada pembelajaran pembentukan perilaku perfeksionisme (Hong, Lee, Cheng, Zhou, Tsai, \& Tan, 2016). Bowers (2012) mengatakan bahwa perfeksionisme berasal dari berbagai faktor, seperti: usaha sosial untuk membuat individu beradaptasi dengan lingkungan, usaha individu untuk untuk menunjukkan pada orang lain bahwa mereka peduli dan menyayangi mereka, individu tumbuh didalam keluarga yang kacau, sensitivitas individu dalam menghindari kekacauan dan masalah, tingginya ekspektasi keluarga mengenai kesuksesan, anak yang dibesarkan oleh orangtua yang memiliki karakteristik kepribadian narsis, usaha individu untuk menjadi bahagia di dalam lingkungan, ekspektasi lingkungan terhadap anak untuk tampil sempurna, dan media yang menyoroti kesempurnaan dan hal-hal yang ideal sehingga mengorientasikan individu kepada nilai-nilai tersebut (Kahraman \& Bedük, 2016).

Perfeksionisme berkembang ketika anak-anak belajar bahwa mereka harus memenuhi ekspektasi pencapaian dan/atau perilaku yang diharapkan oleh orangtua mereka 
(Cook, 2012). Morris dan Lomax (dalam Hong dkk., 2016) mengatakan bahwa anak-anak dengan perfeksionisme yang maladaptif cenderung memiliki orangtua yang terlalu mengontrol dan mengganggu, dan seringkali menetapkan standar performa yang tinggi untuk anaknya, dan tidak menerima segala bentuk kegagalan. Mereka biasanya sangat menekankan pentingnya akademik kepada anak-anak mereka (Alburd \& Parker, dalam Cook, 2012) dan lebih mungkin untuk memaksa anak mereka untuk mencapai nilai yang diharapkan dan bereaksi secara berlebihan ketika mereka melakukan kesalahan.

Silverman (1999) mengatakan bahwa individu yang perfeksionis menetapkan standar yang tinggi untuk diri mereka sendiri, dan kemudian merasa rendah diri, terperangkap dalam perasaan bersalah dan malu jika mereka tidak dapat memenuhi standar tersebut. Selain itu, hal negatif lainnya adalah individu menjadi takut akan masa depan, memaksakan standarnya pada orang lain, dan berusaha menjadi sempurna di banyak bidang secara bersamaan (Silverman, 1999). Dalam seting akademik, dapat berarti individu yang perfeksionis termotivasi akan untuk mendapatkan nilai yang sempurna dalam ujian, dan karena hal tersebut, individu dapat secara drastis menggunakan cara-cara yang tidak seharusnya, seperti menyontek (Nathanson, Paulhus, \& Williams, 2006; Beiling, Israeli, Smith, \& Antony, 2003). Kahraman dan Bedük (2016) mengatakan bahwa kombinasi tekanan dari orangtua, diri sendiri, sosial, media, dan role model yang tidak realistis mendorong individu untuk bekerja keras, merasakan perasaan cemas dan bersalah yang berkepanjangan, yang mana pemikiran bahwa selama mereka tidak sempurna mereka tidak akan dicintai atau diterima. Sehingga, hal tersebut membuat mereka mengarahkan diri mereka untuk menjadi yang terbaik dapat menyebabkan beberapa dari mereka untuk curang (Rule \& Montgomery, 2013; Zhao, Heyman, Chen, \& Lee, 2017). Berdasarkan pertimbangan-pertimbangan di atas, maka peneliti melakukan penelitian mengenai hubungan antara tekanan orangtua, perfeksionisme, dan ketidakjujuran akademik pada pelajar di Jakarta.

\section{METODE}

Partisipan penelitian. Dalam penelitian ini, yang menjadi target populasi adalah pelajar yang bersekolah di wilayah DKI Jakarta, 
dengan kriteria subjek sampel meliputi seseorang yang telah berusia $14-18$ tahun $(\mathrm{M}=$ 16,03 tahun), berjenis kelamin laki-laki atau perempuan yang merupakan pelajar tingkat sekolah menengah atas sederajat. Dalam penelitian ini, peneliti mendapatkan responden sebanyak 600 orang pelajar (364 orang pelajar perempuan dan 236 orang pelajar laki-laki).

Desain penelitian. Penelitian ini menggunakan metode penelitian kuantitatif korelasional, dengan tujuan untuk mengetahui hubungan antara tekanan orangtua, perfeksionisme, dan ketidakjujuran akademik.

Prosedur penelitian. Penarikan sampel dalam penelitian ini menggunakan metode nonprobability sampling dengan teknik purposive sampling, yaitu pemilihan sampel penelitian berdasarkan kriteria tertentu yang terdapat pada responden.

Instrumen penelitian. Penelitian ini menggunakan tiga jenis alat ukur yang masingmasing mengukur tiap variabel penelitian dan kemudian diterjemahkan ke dalam Bahasa Indonesia. Skala academic dishonesty disusun oleh Iyer \& Eastman pada tahun 2008 yang terdiri dari 17 butir. Skala ini kemudian diterjemahkan dan diadaptasi ke dalam Bahasa Indonesia oleh peneliti, dan menghasilkan skor reliabilitas 0.775 setelah dilakukan uji coba. Sedangkan pengukuran tekanan orangtua menggunakan Perceived Parental Pressure Inventory disusun oleh Sebastian pada tahun 1997. Skala ini kemudian diterjemahkan dan diadaptasi ke dalam Bahasa Indonesia oleh peneliti, dan menghasilkan skor reliabilitas 0.745 setelah dilakukan uji coba. Skala ketiga yang digunakan dalam penelitian ini adalah adalah Children-Adolescence Perfectionism Scale yang disusun oleh Flett, Hewitt, Besser, Su, Vaillancourt, Boucher, \& Gale (2016). Skala ini kemudian diterjemahkan dan diadaptasi ke dalam Bahasa Indonesia oleh peneliti, dan setelah dilakukan uji coba menghasilkan skor reliabilitas sebesar 0.813 untuk self-oriented perfectionism dan sebesar 0.752 untuk social prescribed perfectionism. Penyebaran skala penelitian dilaksanakan dengan membagikan skala penelitian kepada pelajar ke beberapa kelas di setiap sekolah.

Teknik analisis. Sebelum melakukan analisis statistik, peneliti melakukan uji asumsi berupa uji normalitas, yaitu pengujian yang dilakukan dengan tujuan untuk membandingkan persebaran data dengan kurva distribusi normal. Pengujian normalitas dalam penelitian ini dilakukan dengan bantuan program Statistical 
Packages for Social Science (SPSS), menggunakan

Kolmogorov-Smirnov.

Selanjutnya, pengujian hipotesis penelitian ini menggunakan korelasi Spearman karena data dalam penelitian ini tidak berdistribusi normal.

\section{HASIL}

Hasil uji korelasi menunjukkan bahwa variabel tekanan orangtua memiliki hubungan positif yang signifikan dengan dengan ketidakjujuran akademik $(\mathrm{p}=0,048<0,05 ; \mathrm{r}=$ 0,081). Artinya, semakin tinggi tekanan orangtua yang diterima/dirasakan oleh pelajar maka semakin tinggi pula ketidakjujuran akademik yang dilakukan oleh pelajar. Kemudian, hasil uji korelasi antara perfeksionisme dengan ketidakjujuran akademik juga menunjukkan hubungan positif yang signifikan $(\mathrm{p}=0,010<0,05 ; \mathrm{r}=0,105)$ yang mengindikasikan bahwa semakin perfeksionis seseorang, maka akan semakin tinggi pula kemungkinan ketidakjujuran akademik yang ia lakukan sebagai pelajar. Hasil uji korelasi antara ketiga variabel tersebut dapat dilihat pada Tabel 1.

Tabel 1 Hasil Uji Korelasi Tekanan orangtua dan Perfeksionisme dengan Ketidakjujuran Akademik Ketidakjujuran akademik

\begin{tabular}{lccl} 
& \multicolumn{1}{c}{$\mathbf{p}$} & $\mathbf{R}$ & \multicolumn{1}{c}{ Simpulan } \\
\hline $\begin{array}{l}\text { Tekanan } \\
\text { orangtua }\end{array}$ & 0,048 & 0,081 & $\begin{array}{l}\text { Berhubungan } \\
\text { secara signifikan } \\
\text { dan positif }\end{array}$ \\
\hline & & & Berhubungan \\
Perfeksionisme & 0,010 & 0,105 & $\begin{array}{l}\text { secara signifikan } \\
\text { dan positif }\end{array}$ \\
\hline
\end{tabular}

Di sisi lain, peneliti juga menguji hubungan antara tekanan orangtua dan perfeksionisme. Hasil uji korelasi menunjukkan terdapat hubungan yang signifikan dan positif antara kedua variabel tersebut $(\mathrm{p}=0,000<$ $0,05 ; \mathrm{r}=0,364)$. Artinya, tekanan orangtua yang dialami oleh pelajar juga dapat menyebabkan perfeksionisme pada pelajar.

\section{DISKUSI}

Ketidakjujuran akademik yang dilakukan pelajar berhubungan dengan beberapa faktor. Dari hasil korelasi dalam penelitian ini menunjukkan bahwa tekanan orangtua dan perfeksionisme memiliki hubungan yang signifikan dengan ketidakjujuran akademik. Berdasarkan Albrecht, Albrecht, Albrecht, \& Zimbelman (2012); tekanan yang dirasakan oleh individu mempengaruhi individu tersebut untuk melakukan perilaku tidak jujur. Dalam konteks penelitian ini, pelajar akan lebih mungkin untuk 
berlaku curang atau tidak jujur secara akademik jika mendapatkan tekanan dari orangtua mereka, terutama tekanan untuk berprestasi. Hasil penelitian yang dilakukan oleh Apriani, Sujana, \& Sulindawati (2017) menemukan bahwa tekanan yang dirasakan individu memiliki pengaruh yang signifikan terhadap kecurangan akademik.

Merupakan hal yang wajar jika orangtua menaruh harapan pada anak mereka. Menurut McDevitt \& Ormrod (2014), harapan dari orangtua kepada anak semakin meningkat seiring bertambahnya usia sang anak terutama ketika mereka memasuki masa remaja. McCabe dan Trevino (1997) mengidentifikasi beberapa alasan mengapa pelajar terlibat dalam ketidakjujuran akademik, salah satunya yaitu karena mereka mendapat tekanan untuk mendapatkan nilai yang tinggi. Taylor et. al. (dalam Sarita, 2015) mengungkapkan bahwa biasanya tekanan tersebut berasal dari orangtua. Orangtua biasanya menaruh perhatian mereka pada nilai-nilai yang diperoleh anak mereka di sekolah, dan beberapa orangtua menjadi berlebihan dalam hal ini yang kemudian memberikan tekanan kepada anak-anak mereka terkait nilai ataupun prestasi yang diperoleh sang anak. McDevitt dan Ormrod (2014) mengatakan bahwa keluarga memainkan peranan penting melalui keterlibatan mereka dalam sekolah anaknya. Pelajar yang orangtuanya terlibat dalam kegiatan sekolah anak mereka, secara umum, memiliki prestasi yang tinggi (Eccless, 2007), namun dalam beberapa kasus, orangtua terlibat dalam kegiatan sekolah anak mereka berujung dengan mendikte anak mereka bagaimana mereka seharusnya di sekolah, atau memberikan tekanan yang berlebihan pada anak-anak mereka untuk berprestasi.

Strom \& Strom mengungkapkan bahwa tingginya tekanan orangtua terjadi ketika anak berusia remaja (dalam Sarita, 2015), dan cara orangtua menekan anak-anak mereka berbedabeda. Beberapa orangtua ada yang secara langsung megungkapkan harapan mereka kepada anak-anaknya untuk mendapat nilai yang tinggi, ada beberapa orangtua yang memberikan hukuman fisik, sementara beberapa orangtua lainnya mendiamkan anak mereka sebagai bentuk kekecewaan mereka (Irfan \& Hussain, 2014). Karena tekanan dari orangtua mereka, remaja tidak jarang mengambil risiko untuk menyenangkan orangtua mereka dengan prestasi yang lebih tinggi daripada teman atau saudara kandung mereka, dan kecurangan akademik sebagai jalan pintas mereka untuk mendapatkan nilai 
yang mereka atau orangtua mereka inginkan karena remaja percaya bahwa dengan berbuat curang sebagai satu-satunya jalan untuk segala kesuksesan.

Hasil korelasi selanjutnya menunjukkan bahwa tekanan orangtua memiliki hubungan yang signifikan dan positif dengan perfeksionisme. Leff \& Hoyle (dalam Irfan \& Hussain, 2014) mendefinisikan tekanan orangtua sebagai perilaku orangtua yang dirasakan anak sebagai ekspektasi yang terlalu tinggi, bahkan tidak mungkin untuk dicapai oleh mereka. Orangtua menekan anak-anak mereka dengan cara yang berbeda-beda, dan mungkin saja tidak memberikan perhatian atau menunjukkan afeksi mereka ketika anaknya melakukan hal yang tidak disukai atau tidak sesuai dengan harapan mereka. Namun, cara tersebut tanpa disadari menimbulkan efek yang mendalam bagi sang anak, karena berdasarkan teori self-determination, anak secara alamiah cenderung menginternalisasi nilai budaya, sikap, dan perilaku yang ada di sekitarnya (Grolnick, 2003), dan mereka akan secara bertahap menggunakannya untuk mengevaluasi perilaku dan karakter mereka. Perilaku negatif dan intrusiveness orangtua juga merupakan prediktor yang kuat for critical self-oriented perfeksionisme (Hong, dkk., 2016). Menurut hasil penelitian Mih (2013), tuntutan yang tinggi terhadap anak dapat menyebabkan meningkatnya perfeksionisme (Sedlakova, Mylek, Capkova, Prochazka, Vaculik, \& Jezek, 2014).

Anak-anak yang perfeksionis seringkali merupakan anak-anak yang memang dibesarkan menjadi individu yang perfeksionis, daripada dilahirkan dengan pola pikir ini (Rule \& Montgomery, 2013). Peneliti terdahulu yang meneliti tentang berasumsi bahwa individu yang perfeksionis berkembang didalam lingkungan dimana cinta dan penerimaan didapat dengan suatu syarat (Frost, Marten, Lahart, \& Rosenblate, 1990). Perfeksionisme berkembang ketika anak-anak belajar bahwa mereka harus memenuhi ekspektasi pencapaian dan/atau perilaku yang ditentukan oleh orangtua untuk mendapatkan cinta dan penerimaan dari orangtua mereka (Flett et al. dalam Cook, 2012). Burns (1980) juga menekankan bahwa anak-anak belajar bahwa kesalahan yang mereka lakukan akan membuat mereka kehilangan penerimaan dari orangtua mereka, sehingga mereka belajar bahwa kesempurnaan akan membuat mereka diterima dan dicintai.

Kebutuhan anak akan cinta, perhatian, dan penerimaan dari orangtua mereka adalah 
yang paling mereka butuhkan sepanjang hidup mereka. Untuk merasa dicintai dan diterima, individu harus melakukan segala sesuatu dengan sempurna, dan segala bentuk kegagalan atau kesalahan akan berakibat penolakan dan kehilangan cinta dari orangtua. Individu yang perfeksionis merasa bahwa orangtua mereka menetapkan standar yang sulit mereka capai, dan kegagalan dalam mencapai standar tersebut berarti akan ada kemungkinan bagi mereka untuk kehilangan cinta dan penerimaan dari orangtua. Hal ini sejalan dan bisa jadi merupakan komponen inti dari perfeksionisme (Frost, Marten, Lahart, \& Rosenblate, 1990). Kombinasi dari tekanan keluarga, diri sendiri, sosial, media, dan role model yang tidak realistik mendorong individu untuk bekerja keras, menjalani hidup dengan perasaan cemas dan perasaan bersalah, yang mana individu tersebut berpikir bahwa selama dirinya tidak sempurna maka dirinya tidak akan dicintai atau diterima oleh orang lain (Kahraman \& Beduk, 2016). Sehingga, secara tidak sadar, individu dengan socially prescribed Perfeksionisme menghasilkan lebih banyak akibat negatif karena mereka merasa bahwa orang lain menetapkan standar yang berlebihan dan tidak bisa mereka kontrol, sehingga individu akan lebih mengkhawatirkan bagaimana ia bisa memenuhi standar orang lain dan menunjukkan ketakutan yang luar biasa akan kritik (Hewitt \& Flett, 1991).

Hasil penelitian juga menunjukkan bahwa perfeksionisme berhubungan secara positif dan signifikan dengan ketidakjujuran akademik. Rimm (2007) menyatakan bahwa kecenderungan perfeksionisme dapat muncul pada beberapa area spesifik, yang mana seseorang bisa saja menjadi perfeksionis dalam prestasi akademik, pakaian dan penampilan, pengaturan dan kebersihan ruangan, kemampuan atletik, atau bakat musik dan seni (Ratna \& Widayat, 2012). Hasil penelitian yang dilakukan oleh McCabe dkk., (1999), ditemukan bahwa salah satu motivasi pelajar terlibat dalam ketidakjujuran akademik adalah karena keinginan individu untuk menjadi unggul (Eriksson \& McGee, 2015).

Berdasarkan hasil pengamatan yang dilakukan oleh Albert Ellis (2002), individu dengan self-oriented perfectionism yang ekstrim mengharuskan kesempurnaan, yang mana mereka tidak hanya ingin menjadi sempurna, melainkan mereka harus menjadi sempurna (Flett dkk., 2016). Self-oriented perfectionism merupakan dimensi yang sangat rumit karena melibatkan elemen dari selfdetermination dan elemen yang berkaitan 
dengan ego yang mengkhawatirkan peneriman diri sendiri dan dari orang lain (Flett dkk., 2016). Individu dengan self-oriented perfectionism memiliki standar yang tinggi yang harus mereka capai. Mereka memiliki motivasi yang kuat untuk menjadi sempurna, yang mana motivasi tersebut berasal dari diri individu itu sendiri, mereka tidak akan terpengaruh dengan motivasi ekstrinsik, kecuali motivasi ekstrinsik tersebut memiliki pengaruh yang besar terhadap individu tersebut. Penelitian Isnaningtyas (2013) mengungkapkan bahwa individu dengan self-oriented perfectionism memiliki keinginan yang kuat untuk mencapai kesempurnaan. Selain itu, mereka tidak menginginkan adanya kesalahan pada pekerjaan yang mereka lakukan dan menjadikan standar tersebut menjadi sebuah perintah untuk dirinya dalam mencapai keinginannya, sehingga mereka akan selalu berusaha keras dalam belajar dan juga dalam pengerjaan tugas-tugas sekolahnya.

Beberapa peneliti sebelumnya menyatakan bahwa orangtua atau orang lain dalam lingkungan sosial individu yang perfeksionis memiliki ekspektasi yang tinggi dalam hal performa, dan Morris \& Lomax (2014) mengungkapkan biasanya mereka cenderung tidak menerima segala bentuk kegagalan (Hong dkk., 2016), yang mengakibatkan individu tersebut akan cenderung untuk menghindari situasi yang kompetitif, dimana mereka tidak cukup yakin dan percaya diri dapat melakukannya dengan baik. Selain itu, tanggapan dari orangtua dan guru pada bagaimana luar biasanya hasil yang dilakukan mereka akan menyebabkan individu tersebut berfokus pada hasil akhir daripada proses pembelajarannya, yang mana hal ini dapat menyebabkan beberapa dari mereka akan berbuat curang, sebagai bentuk upaya mereka mempertahankan diri untuk menjadi yang terbaik (Rule \& Montgomery, 2013; Zhao, Heyman, Chen, \& Lee, 2017).

Tidak seperti banyak penelitianpenelitian sebelumnya yang mengenai kemungkinan perbedaan jenis kelamin individu dalam menyontek atau melakukan hal yang tidak jujur secara yang menunjukkan bahwa laki-laki lebih sering terlibat dalam berbagai bentuk ketidakjujuran akademik dibandingkan perempuan, namun dalam penelitian ini tidak menunjukkan hal yang sama. Hal serupa juga terjadi pada beberapa penelitian sebelumnya (Cahyo \& Solicha, 2017; Costley, 2017) yang juga menunjukkan bahwa tidak ditemukan adanya perbedaan antara kedua jenis kelamin tersebut dalam menyontek atau bentuk 
ketidakjujuran akademik lainnya. Salah satu penjelasan mengenai ketidakkonsistenan hasil penelitian mengenai pengaruh jenis kelamin terhadap perilaku menyontek adalah karena tempat dimana perilaku tersebut terjadi, dan bagaimana cara mengukur perilaku tersebut pada penelitian yang dilakukan (Miller, Murdock, Anderman, \& Poindexter, 2007).

\section{SIMPULAN}

Penelitian ini menghasilkan tiga temuan bahwa: (1) tekanan orangtua yang dipersepsi oleh pelajar berhubungan secara positif dengan ketidakjujuran akademik, (2) perfeksionisme pada pelajar berhubungan secara positif dengan ketidakjujuran akademik, dan (3) tekanan orangtua berhubungan secara positif dengan perfeksionisme. Artinya, tekanan orangtua yang berlebihan kepada remaja, terutama dalam konteks pendidikan, dapat menimbulkan perfeksionisme dan ketidakjujuran akademik pada pelajar remaja di Jakarta. Lebih lanjut lagi, perfeksionisme tersebut juga turut bersumbangsih pada ketidakjujuran akademik pelajar.

\section{DAFTAR PUSTAKA}

Albrecht, W. S., Albrecht, C. O., Albrecht, C. C., \& Zimbelman, M. F. (2012). Fraud examination (4th ed.). South-Western: Cengage Learning.

Anderman, E. M., \& Murdock, T. B. (2006). The psychology of academic cheating. Dalam E. M. Anderman, \& Tamera B Murdock, The psychology of academic cheating (1 ed., hal. 1-5). USA: Elsevier Inc.

Apriani, N., Sujana, E., \& Sulindawati, I. G. (2017). Pengaruh pressure, opportunity, dan rationalization terhadap perilaku kecurangan akademik. e-Journal S1 AK Universitas Pendidikan Ganesha, 7(1).

Beiling, P. J., Israeli, A., Smith, J., \& Antony, M. M. (2003). Making the grade: The behavioural consequences of Perfeksionisme in the classroom. Personality and Individual Differences, 35(1), 163-178.

Benner, A. D., Boyle, A. E., \& Sadler, S. (2016). Parental involvement and adolescents' educational success: The roles of prior achievement and socioeconomic status. $J$ Youth Adolescence. doi:10.1007/s10964-016$0431-4$ 
Bjorklund, M., \& Wenestam, C. G. (1999). Academic cheating: Frequency, methods, and causes. Dalam S. F. Davis, P. F. Drinan, \& T. Bertram, Cheating in school: what we know and what we can do. WestSussex, U.K.: Wiley-Blackwell.

Burns, D. D. (1980). The perfectionist's script for self-defeat. Psychology Today, 14(6), 34-52. Diambil kembali dari http://www.ucdenver.edu/life/services/ counseling-center/Documents/ThePerfectionists-Script-for-SelfDefeat.pdf

Cahyo, S. D., \& Solicha. (2017). Faktor-faktor yang mempengaruhi perilaku menyontek pada pelajar dan mahasiswa di Jakarta. JP3I, 6(1), 8796.

Cook, L. C. (2012). The influence of parent factors on child Perfeksionisme: A cross-sectional study. UNLV Theses, Dissertations, Professional Papers, and Capstones, 1551. Diambil kembali dari http://digitalscholarship.unlv.edu/these sdissertations $/ 1551$
Costa, M., \& Faria, L. (2017). Parenting and parental involvement in secondary school: Focus groups with adolescents' parents. Paidéia, 27(67), 28-36. doi:10.1590/1982-43272767201704

Costley, J. (2017). The instructional factors that lead to cheating in a Korean cyber university context. Interactive Technology and Smart Education. doi:10.1108/ITSE-02-2017-0019

Eastman, J. K., Iyer, R., \& Reisenwitz, T. H. (2008). The impact of unethical reasoning on different types of Ketidakjujuran Akademik: an exploratory study. Journal of College Teaching \& Learning, 5(12), 7-15.

Eriksson, L., \& McGee, T. R. (2015). Ketidakjujuran Akademik amongst Australian criminal justice and policing university students: individual and contextual factors. International Journal for Educational Integrity, 115. doi:10.1007/s40979-015-0005-3

Ferguson, C., \& Rodriguez, V. (2005). Engaging families at the secondary level: What schools can do to support family involvement. Family \& 
Comunity Connection with Schools.

Diambil kembali dari http://www.sedl.org/connections/resou rces/rb/rb3-Secondary.pdf

Flett, G. L., Hewitt, P. L., Besser, A., Su, C., Vaillancourt, T., Boucher, D., \& Gale, O. (2016). The child-adolescent Perfeksionisme scale: Development, psychometric properties, and associations with stress, distress, and psychiatruc symptomps. Journal of Psychoeducational Assessment, 1-19. doi:10.1177/0734282916651381

Frost, R. O., Marten, P., Lahart, C., \& Rosenblate, R. (1990). The dimensions of Perfeksionisme. Cognitive Therapy and Research, 14(5), 449-468.

Grolnick, W. S. (2003). The psychology of parental control. New Jersey: Lawrence Erlbaum Associates, Inc.

Hewitt, P. L., \& Flett, G. L. (1991). Perfeksionisme in the self and social contexts: Conceptualization, assessment, and association with psychopathology. Journal of Personality and Social Psychology, 60(3), 456-470.
Hong, R. Y., Lee, S. S., Cheng, R. Y., Zhou, Y., Tsai, F. F., \& Tan, S. H. (2016). Developmental trajectories of maladaptive Perfeksionisme in middle childhood. Journal of Personality, 114. doi:10.1111/jopy.12249

Irfan, S. M., \& Hussain, N. (2014). Tekanan orangtua on student's attainment of high grades in Karachi based universities. Pakistan Business Review, 156-176.

Isnaningtyas, C. L. (2013). Perfeksionisme siswa program kelas akselerasi SMA Negeri 3 Yogyakarta. Journal Bimbingan Dan Konseling, 2(11).

Josephson Institute. (2009, 10 29). Josephson Institute of Ethics releases study on high school character and adult conduct. Diambil kembali dari http://josephsoninstitute.org/surveys/

Kahraman, S., \& Bedük, Ş. B. (2016). Multiple intelligence and Perfeksionisme in middle school gifted students. Journal for the Education of Gifted Young Scientists, $\quad 4(2)$, $1-13$. doi:http://dx.doi.org/10.17478/JEGYS. 2016219257 
Kessler International. (2017, February 6). Kessler International. Diambil kembali dari PR Newswire: http://www.prnewswire.com/newsreleases/survey-shows-cheating-andacademic-dishonesty-prevalent-incolleges-and-universities300402014.html

Khairat, U., Maputra, Y., \& Rahmi, F. (2014). Pengaruh prokrastinasi akademik terhadap perilaku menyontek pada siswi SMA di Pesantren X. Jurnal RAP UNP, 5(2), 192-203.

Kung, H. Y. (2016). The relationships among parents' socioeconomic status, parental involvement and academic achievement in Taiwanese middle school students. Journal of Education and Human Development, 5(4), 177186. doi:10.15640/jehd.v5n4a17

Kusrieni, D. (2014). Hubungan efikasi diri dengan perilaku menyontek. Psikopedagogia, 3(2), 100-111.

Lestari, S., \& Asyanti, S. (2015). Apakah siswa SMP berperilaku tidak jujur dalam situasi ulangan? The 2nd University Research Coloquium 2015.
Letha. (2013). A study of adolescents' perception of parental influence on academic activities. International Journal of Psychology and Counseling, 5(4), 66-71. doi:10.5897/IJPC12.031

Ma, Y., Siu, A., \& Tse, W. S. (2018). The role of high parental expectations in adolescents' academic performance and depression in Hong Kong. Journal of Family $\quad$ Issues, $1-18$. doi:10.1177/0192513X18755194

McCabe, D. L., \& Trevino, L. K. (1997). Individual and contextual influences on Ketidakjujuran Akademik: A multicampus investigation. Research in Higher Education, 38(3), 379-396. doi:10.1023/A:1024954224675

McDevitt, T. M., \& Ormrod, J. E. (2014). Child development and education (5th ed.). Harlow: Pearson Education.

Miller, A. D., Murdock, T. B., Anderman, E. M., \& Poindexter, A. L. (2007). Who are all the cheaters? Characteristics of academically dishonest students. Dalam E. M. Anderman, \& T. B. Murdock, Psychology of academic 
cheating (hal. 9-32). San Diego:

Elsevier Academic Press.

Nathanson, C., Paulhus, D. L., \& Williams, K. M. (2006). Predictors of a behavioral measure of scholastic cheating: Personality and competence but not demographics. Contemporary Educational Psychology, 31, 97-122. doi:10.1016/j.cedpsych.2005.03.001

Nursalam, Bani, S., \& Munirah. (2013). Bentuk kecurangan akademik (academic cheating) mahasiswa PGMI fakultas tarbiyah dan keguruan UIN Alauddin Makassar. Lentera Pendidikan, 16(2).

Palar, P. M., Palandeng, H., \& Kallo, V. D. (2015). Hubungan peran orangtua dengan prestasi belajar anak usia sekolah di SDN Inpres I Tumaratas kecamatan Langowan Barat. ejournal Keperawatan, 3(2).

Pope, D. C. (2001). Doing school: how we are creating a generation of stressed out, materialistic and miseducated students. London: Yale University Press.

Pradana, O. A., \& Lestari, S. (2016). Dinamika psikologis perilaku curang dalam situasi praktek pada siswa sekolah menengah kejuruan. The 4th University Research Coloquium 2016, (hal. 110121).

Ratna, P. T., \& Widayat, I. W. (2012). Perfeksionisme pada remaja gifted. Insan, 14(3), 203-210.

Rujoiu, O., \& Rujoiu, V. (2014). Ketidakjujuran Akademik and workplace dishonesty. Proceedings of the 8th International Management Conference, (hal. 928-938). Bucharest.

Rule, A. C., \& Montgomery, S. E. (2013). Using cartoons to teach about Perfeksionisme: Supporting gifted students' social-emotional development. Gifted Child Today, $36(4)$, 255-262. doi:10.1177/1076217513497574

Saana, S. B., Ablordeppey, E., Mensah, N. J., \& Karikari, T. K. (2016). Ketidakjujuran Akademik in higher education: students' perceptions and involvement in an African institution. $B M C$ Research Notes, 9. doi:10:1186/s13104-016-2044-0 
Sangma, Z. M., K, S., Akoijam, B. S., Maisnam, A. B., Visi, V., \& Vanlalduhsaki. (2018). Perception of students on parental and teachers' pressure on their academic performance. IOSR Journal of Dental and Medical Sciences, 17(1), 67-75. doi:10.9790/0853-1701016875

Sarita, R. D. (2015). Academic cheating among students: Pressure of parents and teachers. International Journals of Applied Research, 1(10), 793-797.

Sedlakova, J., Mylek, V., Capkova, K., Prochazka, J., Vaculik, M., \& Jezek, S. (2014). Parental control of child as a predictor of academic procrastination. Proceedings of the 11th International Conference on Efficiency and Responsibility in Education 2014 (hal. 694-702). Prague: Czech University of Life Sciences Prague. Diambil kembali dari

https://is.muni.cz/repo/1185489/en/Se dlakova-Mylek-CapkovaProchazka/Parental-control-of-childas-a-predictor-of-academicprocrastination?lang=en
Silverman, L. K. (1999). Perfeksionisme. Gifted Education International, 13, $216-225$

Suara Pembaruan. (2013, 10 2). Survei UPI: Kecurangan UN libatkan guru dan kepala sekolah. Diambil kembali dari http://sp.beritasatu.com/home/surveiupi-kecurangan-un-libatkan-guru-dankepala-sekolah/42791

The Daily Nerbaskan. (2017, April 13). Ketidakjujuran Akademik on the rise, UNL manages to limit the problem. Diambil kembali dari http://www.dailynerbaskan.com/news/ academi-dishonesty-on-the-rise-unlmanages-to-limit-the/article_d4f518fc1ffe-11e7-8408-6b5fba5a076b.html

Zhao, L., Heyman, G. D., Chen, L., \& Lee, K. (2017). Praising young children for being smart promotes cheating. Psychological Science, 28(12), 18681870. doi:10.1177/0956797617721529 